\title{
STRATEGI DAN PENDEKATAN GURU PENDIDIKAN AGAMA ISLAM DALAM PEMBINAAN KEBERAGAMAAN REMAJA
}

\author{
Arni Zulianingsih 1) * \\ ${ }_{1}^{1}$ Program Studi Magister Pendidikan Agama Islam, \\ Universitas Islam Sultan Agung, Semarang \\ *E-mail: arnizulianingsih@gmail.com
}

\begin{abstract}
The Strategy and Approach of Teachers of Islamic Education in Youth Religious Development is a qualitative research that aims to describe the phenomenon and context in implementing religious formation. This research is a case study because the focus of this study answers the question of "how to" religious development and wants to cover contextual conditions that are relevant to the phenomenon. The results of this study indicate that the strategies in youth religious development here are divided into three, namely planning, implementation and evaluation. Whereas the approach in religious development uses a contextual approach, including planning and learning processes carried out in accordance with contextual steps. And in adolescent diversity there are several patterns of religious formation, including: a. Coaching carried out by Islamic Education teachers, and $b$. Religious development by schools and teachers in addition to Islamic Education. The conclusion of the strategy and approach of the teacher of Islamic Education has a positive and significant influence on the religious development of adolescents.
\end{abstract}

Keywords: Strategy, Approach, Diversity Development.

\begin{abstract}
Abstrak
Strategi dan Pendekatan Guru Pendidikan Agama Islam dalam Pembinaan Keberagamaan Remaja merupakan penelitian kualitatif yang bertujuan mendeskripsikan fenomena dan konteks dalam pelaksanaan pembinaan keberagamaan. Penelitian ini merupakan penelitian studi kasus karena fokus penelitian ini menjawab pertanyaan "bagaimana" pembinaan keberagamaan dan ingin meliputi kondisi kontekstual yang relevan dengan fenomenanya. Hasil penelitian ini menunjukkan bahwa strategi dalam pembinaan keberagamaan remaja disini dibagi tiga, yakni perencanaan, pelaksanaan dan evaluasi. Sedangkan pendekatan dalam pembinaan keberagamaan menggunakan pendekatan kontekstual, meliputi perencanaan dan proses pembelajaran yang dilakukan sesuai dengan langkah-langkah kontekstual. Dan dalam keberagamaan remaja terdapat beberapa pola pembinaan keberagamaan, antara lain: a. Pembinaan yang dilakukan oleh guru Pendidikan Agama Islam, dan b. Pembinaan keberagamaan oleh sekolah dan guru selain Pendidikan Agama Islam. Kesimpulannya dari strategi dan pendekatan guru Pendidikan Agama Islam mempunyai pengaruh yang positif dan signifikan terhadap pembinaan keberagamaan remaja.
\end{abstract}

Kata Kunci: Strategi, Pendekatan, Pembinaan Keberagamaan

\section{PENDAHULUAN}

Masa remaja merupakan masa peralihan yang ditempuh seseorang dari kanakkanak menuju dewasa, atau merupakan kepanjangan dari masa kanak-kanak sebelum mencapai dewasa (Zakiyah Darajat, 1978: 69). Dalam masa peralihan yang demikian, seorang remaja telah seperti orang dewasa, hanya saja belum matang perkembangan 
jiwanya, segi emosi dan sosialnya masih memerlukan waktu untuk berkembang menjadi dewasa.

Remaja memiliki beberapa karakter yang khas, salah satunya adalah dorongan untuk berprestasi (Singgih, D. Gunarsa, (1991: 139). Dorongan berprestasi ini akan memacu seseorang remaja untuk berkarya, karena prestasi yang diperolehnya akan mengaktualisasikan perannya ditengah-tengah masyarakat, sesuai dengan jiwanya, seorang remaja berusaha untuk menemukan jati dirinya. Seringkali terlihat remaja terombang ambing dalam gejolak emosi yang tidak terkuasai yang kadang-kadang berpengaruh terhadap kesehatan atau sekurang-kurangnya pada kondisi jasmani. Bahkan pada diri remaja sering mengalami kegoncangan jiwa dan kebimbangan serta berubah-ubah pendirian.

Pada masa remaja, remaja mulai ragu-ragu terhadap keyakinann agamanya. Sebagian besar itu kebimbangan terjadi akibat pertumbuhan. Dalam pertumbuhan, remaja merasa bahwa cara berfikirnya yang kekanak-kanakan tidak sesuai dengan kematangan yang dicapainya. Banyak seniman yang merasa gagal dalam memberikan pendidikan agama kepada anak-anaknya pada masa kanak-kanak pertama, karena kebimbangan yang dirasakan remaja terhadap keyakinan agamanya. Kebimbangan remaja adalah bukti ia bersedia memikirkan persoalan hidupnya yang rumit dan penting (H.H. Remmes dan Hackett, tth: 68).

Segala persoalan dan problema yang terjadi pada remaja-remaja itu sebenarnya bersangkut paut dan kait-berkait dengan usia yang mereka lalui, dan tidak dapat dilepas dengan pengaruh lingkungan dimana mereka tinggal. Dalam hal itu, suatu faktor penting yang menentukan dalam kehidupan remaja adalah agama (Zakiyah Darajat, 1976: 86).

Agama mempunyai peranan yang paling penting dalam kehidupan manusia. Agama merupakan pedoman, pembimbingan dan pendorong dalam diri manusia untuk mencapai kualitas hidup yang baik dan sempurna (Yunan Nasution, 1988: 75). Salah satu wujud kehidupan masyarakat yang berpegang pada moralitas hanya bisa melalui pendidikan, khususnya pendidikan agama. Karena pendidikan agama merupakan usaha memperkuat iman dan taqwa kepada Tuhan Yang Maha Esa sesuai dengan agama yang dianut oleh peserta didik yang bersangkutan. Pendidikan agama berkaitan erat dengan pendidikan yang berkenaan dengan aspek-aspek sikap dan nilai spiritual dan moral (Yunan Nasution, 1988: 76). 
Untuk mewujudkan hal tersebut maka seorang guru pendidikan agama Islam mampu berupaya menggunakan beberapa strategi dan pendekatan dalam pembinaan keberagamaan remaja, baik itu strategi dan pendekatan dalam penyampaian materi agama Islam, dengan menggunakan metode atau strategi, dan pendekatan tentang kegiatan apa saja yang harus dilaksanakan dalam pemembinaan keberagaman remaja, karena dengan menggunakan strategi dan pendekatan dapat menghasilkan tujuan yang diinginkan dalam pendidikan.

Strategi yang harus dilakukan oleh guru Pendidikan Agama Islam dalam pembinaan keberagaman remaja, selain menggunakan metode dalam penyampaian materi juga harus ditunjang dengan adanya keteladanan atau pembiasaan tentang sikap yang baik, tanpa adanya pembinaan tersebut akan sulit mencapai tujuan yang diharapkan, dan sudah menjadi tugas guru pendidikan agama Islam untuk memberikan keteladan atau contoh yang baik dan membiasakannya bersikap baik pula.

Dengan demikian strategi merupakan komponen yang penting dan mempunyai pegaruh yang besar terhadap keberhasilan pembinaan karena dengan adanya strategi dan pendekatan guru Pendidikan Agama Islam dalam pembinaan keberagamaan remaja, selain untuk memaksimalkan dan memudahkan proses pembinaan keberagamaan remaja yang bertujuan untuk meningkatkan mutu guru Pendidikan Agama Islam khususnya peningkatan dalam bidang cara pembelajarannya, yang mana strategi tersebut merupakan jembatan penghubung dalam kegiatan belajar mengajar.

\section{PEMBAHASAN}

\section{A. Pengertian Strategi dan Pendekatan Pembinaan Keberagamaan}

\section{Strategi Keberagamaan}

Strategi keberagamaan tidak dapat diartikan secara implisit dari kedua term yang ada, penulis perlu menjelaskan satu persatu mengenai pengertian "strategi dan keberagamaan". Strategi adalah suatu langkah-langkah terencana yang berisi tentang rangkaian kegiatan-kegiatan yang telah didesain sedemikian rupa oleh seseorang secara cermat yang disesuaikan dengan tujuan yang hendak dicapai. Sedangkan keberagamaan adalah adanya kesadaran diri individu dalam menjalankan suatu ajaran dari suatu agama yang dianut. 
Berangkat dari pengertian di atas, maka menurut hemat penulis bahwa pengertian strategi keberagamaan merupakan langkah-langkah terencana yang dilakukan oleh seseorang yang berisi tentang kegiatan-kegiatan untuk mengetahui seberapa jauh seseorang taat dalam menjalankan ajaran agama yang dianut dengan kesadaran dirinya.

\section{Pendekatan Keberagamaan}

Pembentukan sikap keberagamaan seseorang dapat dilakukan dengan melalui tiga pendekatan yaitu pendekatan rasional, pendekatan emosional dan pendekatan keteladanan.

\section{a. Pendekatan Rasional}

Pendekatan rasional adalah usaha memberikan peranan pada rasio (akal) peserta didik dalam memahami dan membedakan berbagai bahan ajar dalam standar materi serta kaitannya dengan perilaku yang buruk dalam kehidupan duniawi (Ramayulis, 2004: 152).

\section{b. Pendekatan Emosional}

Pendekatan emosional adalah upaya untuk mengugah perasaan emosi peserta didik dalam menghayati perilaku yang sesuai dengan ajaran Islam dan budaya bangsa (serta dapat merasakan mana yang baik dan buruk) (Ramayulis, 2004: 151). Dalam konteks ini terdapat dua metode:

1) Metode nasihat yang merupakan salah satu metode dalam membentuk sikap keberagamaan anak, mempersiapkannya secara normal, psikis, dan sosial, dikarenakan nasihat sangat berperan dalam menjelaskan kepada anak tentang segala hakekat, menghiasi dengan moral mulia dan mengajari tentang prinsip-prinsip Islam. Dalam menggunakan metode nasihat, hendaknya pendidik menghindari perintah atau larangan secara langsung, sebaiknya menggunakan teknik-teknik tidak langsung seperti membuat perumpamaan (Hery Neor, 1995: 1152).

2) Metode pengawasan yaitu seorang pendidik mendampingi dan mengawasi anak didiknya baik dalam hal jasmani maupun rohani dalam upaya membentuk akidah, moral dan sosial yang baik. Aspek pengawasan juga harus memberikan nilai yang positif dan optimal, oleh karena itu harus dilakukan dengan cara yang tidak terlalu mengekang anak, akan tetapi dengan cara menjelaskan dengan baik dan mudah dimengerti oleh anak. 


\section{c. Pendekatan Keteladanan}

Pendekatan keteladanan adalah menjadikan figur guru agama dan non agama dan seluruh warga sekolah sebagai cermin manusia yang berkepribadian agama. Keteladanan dalam pendidikan amat penting dan lebih efektif, apalagi dalam usaha pembentukan sikap keberagamaan, seorang anak akan lebih mudah memahami atau mengerti bila ada seorang yang dapat ditirunya. Keteladanan ini pun menjadi media yang amat baik bagi optimalnya pembentukan jiwa keberagamaan seseorang. "Keteladanan pendidik terhadap peserta didik kunci keberhasilan dalam mempersiapkan dan membentuk moral spiritual dan sosial anak" (Hery Neor, 1995: 154).

\section{Pembinaan Keberagamaan}

\section{a. Pembinaan}

Dalam konteknya dengan suatu kehidupan beragama, pembinaan dapat berarti suatu usaha, tindakan dan kegiatan yang dilakukan secara berdaya guna berhasil dalam memperoleh hasil yang lebih baik (Departemen Pendidikan dan Kabudayaan, 1988: 177).

Secara umum banyak pendapat yang mendefinisikan bahwa pembinaan adalah suatu usaha yang dilakukan secara sadar, berencana teratur dan terarah serta bertanggung jawab untuk mengembangkan kepribadian dengan segala aspeknya (Depag RI, 1983: 6). Dilihat dari prakteknya, pembinaan adalah suatu usaha yang dilakukan secara sadar, berencana teratur dan terarah serta bertanggung jawab untuk mengembangkan kepribadian dengan segala aspeknya (Depag RI, 1983: 6). Dilihat dari prakteknya, pembinaan dapat berupa bimbingan, pemberian informasi, stimulasi, persuasi, pengawasan dan juga pengendalian yang pada hakikatnya adalah menciptakan suasana yang membantupengembangan bakat-bakat positif dan juga pengendalian nilai-nilai yang rendah.

Dengan demikian jelaslah bahwa pembinaan merupakan program di mana para peserta atau anak bina berkumpul untuk menerima dan mengolah informasi, pengetahuan dan kecakapan, baik dengan mengembangkannya atau menambah yang baru. Pembinaan juga dapat difahami sebagai usaha dengan sengaja terhadap peseta didik oleh pendidik untuk mencapai tujuan tertentu dari pendidikan. 


\section{b. Keberagamaan}

Sedangkan keberagamaan atau religiusitas menurut Islam adalah melaksanakan ajaran agama atau ber-Islam secara menyeluruh (Q.S 2: 208). Oleh karena itu, setiap muslim baik dalam berpikir, bersikap maupun bertindak diperintahkan untuk ber-Islam. Keberagamaan atau religiusitas, dapat diwujudkan dalam berbagai sisi kehidupan manusia. Aktivitas beragama tidak hanya terjadi ketika seseorang melakukan perilaku ritual (beribadah), tetapi juga ketika melakukan aktivitas lain yang didorong oleh kekuatan supranatural. Bukan hanya yang berkaitan dengan aktivitas yang tampak oleh mata, tetapi juga yang tidak tampak dan terjadi dalam hati (Muhaimin, dkk., 2001: 293).

Jalaluddin Rahmat (1989: 57) mendefinisikan keberagamaan sebagai perilaku yang bersumber langsung atau tidak langsung kepada Nash. Keberagamaan juga diartikan sebagai kondisi pemeluk agama dalam mencapai dan mengamalkan ajaran agamanya dalam kehidupan atau segenap kerukunan, kepercayaan kepada Tuhan Yang Maha Esa dengan ajaran dan kewajiban melakukan sesuatu ibadah menurut agama.

Berangkat dari pengertian di atas maka menurut hemat penulis bahwa pengertian pembinaan keberagamaan yang dimaksud adalah usaha yang dilakukan seorang pendidik terhadap peserta dengan sengaja untuk mengetahui sebarapa jauh seseorang taat kepada ajaran agama dengan cara menghayati dan mengamalkan ajaran agama tersebut yang meliputi cara berfikir, besikap, serta berperilaku baik dalam kehidupan pribadi dan kehidupan sosial masyarakat yang dilandasi ajaran agama Islam (Hablum Minallah dan Hablum Minannas) yang diukur melalui dimensi keberagamaan yaitu dimensi keyakinan yang disejajarkan dengan akidah, dimensi praktik agama disejajarkan dengan syari'ah dan dimensi pengalaman disejajarkan dengan akhlak.

\section{Pentingnya Penanaman Nilai Agama bagi Remaja}

Keberagamaan pada remaja adalah keadaan peralihan dari kehidupan beragama anak-anak menuju kearah kemantapan beragama (A. Ahyadi, 1988). Sifat kritis terhadap ajaran agama mulai timbul pada masa remaja. Mereka mulai menemukan pengalaman dan penghayatan ketuhanan yang bersifat 
individual. Keislaman mulai otonom, hubungan dengan Tuhan mulai disertai dengan kesadaran dan kegiatannya dalam masyarakat semakin diwarnai oleh rasa keagamaan.

Daradjat (1993) mengemukakan bahwa pada masa remaja mulai ada keraguan terhadap kaidah akhlak dan ketentuan agama. Mereka tidak mau lagi menerima ajaran-ajaran agama begitu saja seperti pada masa kanak-kanak. Bahkan, apa yang telah didapatkan dahulu pada masa remaja mulai dipertanyakan atau diragukan lagi secara kritis seperti benarkah Tuhan itu ada? Mengapa manusia harus menyembah Tuhan? Mengapa shalat harus menghadap kiblat? Jadi pada masa ini remaja sudah mulai berfikir kritis sehingga mengalami konflik dan keraguan dalam beragama. Pendapat yang sama ditambahkan oleh Hurlock (1973) bahwa remaja mulai meragukan tentang isi kitab sucinya dan doktrin-doktrin agamanya. Pada masa remaja muncul peluang terjadinya konflik dan keraguan dalam pemahaman agama. Peluang terjadinya konflik dan keraguan itu menurut Flower karena pada masa ini seseorang mengandalkan kekuatan akal pemikiran kritis dan rasionalitas dalam mengetahui dan memahami sesuatu.

\section{Membina Kehidupan Beragama pada Remaja}

Seperti yang telah dikemukakan di atas bahwa yang mendapat sasaran dalam pembinaan agama adalah mereka yang berada dalam masa remaja yang bisa lepas begitu saja untuk bertanggung jawab sendiri atas pembinaan pribadinya. Tidak mudah menentukan cara atau metode yang tepat dan baik bagi remaja itu, namun sekedar pegangan disini ada beberapa hal yang perlu mendapat perhatian antara lain:

\section{a. Tunjukkan Kepada Mereka Bahwa Kita Dapat Memahami Mereka}

Sesorang yang ingin membina jiwa harus dapat memahami orang yang akan dibinanya, seperti ciri-ciri, sifat dan problem yang sedang dihadapinya serta dapat mengetahui apa yang telah mereka rasakan.

\section{b. Pembinaan Secara Konsultasi}

Seharusnya setiap pembinaan kehidupan beragama itu menyadari bahwa yang dibina itu adalah jiwa yang bersifat abstrak tidak dapat dipegang atau diketahui secara langsung, oleh karena itu hendaklah pembinaan tersebut 
terbuka untuk menampung atau mendengar ungkapan-ungkapan perasaan yang dialami oleh masing masing remaja.

Dengan demikian, yang sangat diperlukan dalam halini adalah kemampuan untuk mendengar secara baik dan aktif, inilah yang dinamakan seni dengar, dengan tantangannya segala apa yang dirasakan oleh remaja tersebut maka akan terbukalah hati mereka sesudah itu untuk menerima penyelesaian bagi problem tersebut.

\section{c. Dekatkan Agama Pada Hidup}

Hukum dan ketentuan agama itu perlu mereka ketahui, yang lebih penting lagi yang menggerakkan hati mereka untuk memenuhi hukum dan ketentuan agama. Jangan sampai pengertian dan pengetahuan mereka tentang agama hanya sekedar pengetahuan yang tidak berpengaruh apa-apa dalam kehidupan mereka sehari-hari.

Untuk itu diperlukan usaha pendekatan agama dengan segala ketentuan kepada kehidupan sehari-hari dengan jalan mencari hikmah dan manfaat setiapketentuan agama itu. Jangan sampai mereka meyangka bahwa hukum dan ketentuan agama merupakan perintah Tuhan yang terpaksa mereka patuhi tanpa merasakan manfaat dari kepatuhan itu.

\section{B. Strategi Guru Pendidikan Agama Islam dalam Pembinaan Keberagamaan}

\section{Remaja}

Strategi guru Pendidikan Agama Islam dalam pembinaan keberagamaan semua tidak lepas dari peran kepala sekolah, waka kurikulum, dan guru Pendidikan Agama Islam.

\section{Strategi Guru PAI dalam Membuat Perencanaan Pembinaan Keberagamaan}

Perencanaan selalu pro aktif memberi saran, pendapat, menampung ide.

Guru Pendidikan Agama Islam selalu menggali ide-ide tentang bagaimana strategi peningkatan dan terobosan-terobosan menuju efektifitas pembelajaran. Dan jika menurut kepala sekolah ide dari guru Pendidikan Agama Islam tersebut yang belum efektif dan efisien maka kepala sekolah akan memberi masukan-masukan atau saran yang kemudian didiskusikan bersama. Inovasi program dan strategi program dan menyelaraskan kurikulum yang ada. 
Setelah menerima ide maupun inovasi yang digagas guru Pendidikan Agama Islam waka kurikulum menyusun dan menimbang bobot program tersebut dengan kurikulum yang ada sebelum kemudian dipresentasikan dihadapan kepala sekolah. Selanjutnya jika perencanaan inovasi program dan strategi program disetujui oleh kepala sekolah maka waka kurikulum bertugas untuk mengkoordinasikan program tersebut.

Menurut Muhibbin Syah, ada sepuluh kompetensi dasar yang harus dimiliki guru dalam upaya peningkatan keberhasilan belajar mengajar, yaitu : menguasai bahan, mengelola program belajar mengajar, mengelola kelas, menggunakan media atau sumber belajar, menguasai landasan-landasan kependidikan, mengelola interaksi belajar mengajar, menilai prestasi siswa untuk pendidikan dan pengajaran, mengenal fungsi dan program pelayanan bimbingan dan penyuluhan, mengenal dan menyelenggarakan administrasi sekolah, memahami prinsip-prinsip dan menafsirkan hasil-hasil pendidikan guna keperluan pengajaran (Syaiful Bahri Djamarah, 2010: 43).

Siswa dituntut dan harus siap dengan aplikasi perencanaan program yang diterima dengan mendapatkan pelajaran ekstra yang bersumber dari kitab kuning. Siswa mau tak mau dengan dunia pembelajaran baru yang menggali dari beberapa sumber sehingga siswa selalu cermat dan seksama terhadap pelajaran.

\section{Strategi Guru Pendidikan Agama Islam dalam Pelaksanaan Pembinaan} Keberagaman

Mengawali strategi program yang telah di buat dan disetujui. Dalam tatanan pelaksanaan kepala sekolah mengawasi program yang telah disusun dan disetujui guru Pendidikan Agama Islam karena kepala sekolah perlu mengawasi setiap strategi yang telah dibuat oleh guru Pendidikan Agama Islam yang kemudian disetujui.

Memberikan bimbingan dan sering ide dengan guru Pendidikan Agama Islam. Waka kurikulum sebagai orang pertama yang mendampingi guru Pendidikan Agama Islam dalam melaksanakan program dengan harapan program tersebut tidak keluar dari kurikulum. Sehingga guru Pendidikan Agama Islam tidak menemui hambatan ditengah melaksanakan program yang telah dibuat. 
Melaksanakan program yang telah dibuat dan di sahkan dengan selalu engevaluasi setiap waktu. Guru Pendidikan Agama Islam dari keterangan yang kami himpun, mempunyai konsekuensi moral karena takut dikemudian hari program yang telah disusun secara matang tidak seperti apa yang diharapkan. Dalam sistem pembelajaran (maksutnya pembelajaran sebagai suatu sistem), evaluasi merupakan salah satu komponen penting dan tahap yang harus ditempuh oleh guru untuk mengetahui keefektifan pembelajaran.

Siswa selalu siap semua materi yang diajarkan. Dengan model pelajaran yang diterapkan siswa selalu dituntut mempersiapkan dan sisi materi yang disajikan. Sebelum materi diajarkan, pada pertemuan sebelumnya guru memeberi tahu materi pelajaran yang akan diajarkan pada pertemuan yang akan datang. Jadi, siswa bisa mempelajari materi tersebut sebelumnya dan pada waktu diajarkan sudah menguasai walaupun hanya $50 \%$.

\section{Strategi Guru Pendidikan Agama Islam dalam Evaluasi Pembinaan Keberagaman}

Dari sisi evaluasi, kepala sekolah bertanggung jawab melaksanakan program dengan guru Pendidikan Agama Islam, serta mencermati secara seksama dari sisi positif setelah program itu dilaksanakan dengan menyelaraskan dengan kurikulum yang ada.

Dengan adanya strategi program yang telah dibuat oleh guru Pendidikan Agama Islam nampak pelajaran ini terserap sesuai rencana. Dengan adanya inovasi program dari guru PAI efisiensi waktu dan maksimalisasi program benar-benar nampak dan terwujud.

Pemahaman murid rata-rata terserap 60\% tidak jarang siswa yang berasal dari madrasah 90\%. Melihat latar belakang murid yang didominasi dari sekolah asal yang pendidikan agamanya minim, namun rata-rata nilai didapat dengan strategi program yang telah dibuat.

Siswa merasa tidak biasa dengan materi yang diajarkan Pendidikan Agama Islam karena didominasi murid yang notabennya Pendidikan Agama Islam pelajarannya minim tidak jarang di sana sini murid banyak yang menemui kesulitan. 


\section{Pendekatan Guru Pendidikan Agama Islam dalam Pembinaan Keberagamaan Remaja}

Pendekatan pembelajaran pada kurikulum 2013 juga dijalankan dengan baik, hal ini sesuai dengan konsep pada pendekatan saintifik sendiri, pembelajaran dengan pendekatan saintifik merupakan pembelajaran yang dilakukan agar peserta didik secara aktif mampu menyusun konsep, hukum, atau prinsip melalui tahapantahapan mengamati (untuk mengidentifikasi atau menemukan masalah), merumuskan masalah, mengajukan atau merumuskan hipotesis, mengumpulkan data dengan berbagai teknik, menganalisis data, menarik simpulan dan mengomunikasikan konsep, hukum atau prinsip yang "ditemukan" tersebut.

Pembelajaran dengan pendekatan saintifik dapat diterapkan dalam pembelajaran untuk mata pelajaran Pendidikan Agama Islam dan pembinaan keberagamaan dengan karaktristik sebagai berikut:

1. Pembelajaran berpusat pada peserta didik

2. Melibatkan keterampilan proses sains dalam menyusun konsep, hukum atau prinsip

3. Melibatkan proses-proses kognitif yang potensial dalam merangsang perkembangan intelektual, khususnya keterampilan berpikir tingkat tinggi peserta didik, dan

4. Dapat mengembangkan karakter peserta didik.

Pendekatan saintifik dan pembelajaran kontekstual merupakan pendekatan dan model yang berpusat pada peserta didik agar peserta didik berusaha menemukan sendiri beragam informasi yang dibutuhkan .

Pembelajaran kontekstual sendiri adalah pembelajaran yang menekankan pada proses keterlibatan peserta didik menemukan materi yang dipelajari dan menghubungkannya dengan kehidupan nyata (konteks kehidupan sehari-sehari, seperti konteks pribadi, sosial, dan budaya) dan menerapkannya dalam kehidupan sehari-hari (Amin Haedari, 2013: 21). Proses demikian akan mengakrabkan peserta didik dengan lingkungannya, baik lingkungan keluarga, masyarakat, maupun dunia kerja.

Kegiatan peserta didik dalam pembelajaran dengan pendekatan konteksual dapat dengan menggunakan salah satu model pendekatan kontekstual atau memadukan dengan model lainnya. Langkah-langkah pembelajaran berdasarkan 
82 | Arni Zulianingsih

pembelajaran konteksual mencakup apa saja, dapat dicermati pada komponen pembelajaran kontekstual berikut ini :

1. Peserta didik menyusun pengetahuan dan keterampilannya sedikit demi sedikit.

2. Peserta didik aktif untuk bertanya sebagai wujud rasa ingin tahun.

3. Peserta didik menemukan sendiri pengetahuan dan keterampilannya (inkuiri).

4. Peserta didik membentuk kelompok atau masyarakat belajar

5. Terdapat model yang dapat ditiru

6. Terdapat refleksi dalam pembelajaran

7. Menggunakan penilaian otentik.

\section{Keberagamaan Remaja}

\section{Pembiasaan Siswa dalam Melaksanakan Ibadah}

Dalam pembinaan keberagamaan remaja atau siswa bukan hanya terlepas dari teori semata, dari sisi pengajar (pendidik/guru) dapa dipastikan bahwa guru beragama Islam serta senantiasa baik akhlak dan budi pekertinya. Syarat wajib yang harus dipenuhi oleh seluruh guru (pendidik). Hal ini dimasudkan untuk mempermudah Islamisasi ilmu pengetahuan ke dalam proses kegiatan belajar mengajar di kelas. Hal yang bisa peneliti amati dari seluruh guru satu visi dan satu misi di bawah naungan lembaga pendidikan Ahlus sunnah wal jamaah (NU). Kompetensi Guru Agama Islam dibekali dengan materi, metode mengajar yang mumpuni dan berkarakter Islami. Proses KBM yang terlihat pun bukan hanya berakhir di atas kertas saja melainkan aplikatif dan penerapan.

Penanaman nilai luhur Pendidikan Agama Islam senantiasa tercermin dalam kurikulum, sebagaimana yang termaktub dalam uatan KTSP dan K-13 terlebih pada rumpun Pendidikan Agama Islam, di dalamnya terbagi rumpun : Fiqih, Bahasa Arab, Tarikh (Sejarah Kebudayaan Islam), Akidah Akhlak,dan alQur'an Hadits. Materi Pendidikan Agama Islam yang tersusun kemudian diaplikasikan ke dalam bentuk pelaksanaan, misalnya dalam membina minat baca tulis al-Qur'an diberikannya teori yang berkenaan dengan membaca alQur'an. Guru kemudian memberikan tugas untuk menunjuk menjadikan imam pada shalat dhuha berjamaah. 
Tugas Pembinaan keberagamaan bukan hanya terletak di pundak guru Pendidikan Agama Islam semata. Terbukti setiap guru dibekali kompetensi yang matang dan cakap dalam membina sikap/moralitas anak didik. Guru selain Pendidikan Agama Islam dituntut dapat memberikan uswatun hasanah, terbukti setiap guru digilir untuk menjadi imam shalat dhuhur dan kegiatan lainnya.

\section{Berdoa di Awal dan Akhir Pelajaran}

Dalam upaya pembentukan sikap, sebagaimana terlihat dalam pengamatan. Peneliti melihat siswa sedang khusuk mengikuti doa apel pagi masuk sekolah pada jam pertama (07.00 WIB). Pelaksanaan dipimpin oleh ketua kelas kemudian diikuti oleh seluruh siswa dan guru. Pola penerapan pembinaan ini dapat dan mampu memberikan nutrisi keislaman dan sikap untuk bersyukur. Selanjutnya pada akhir pelajaran guru menyampaikan pesan dan amanat kepada siswa yang intinya untuk senantiasa menjaga pergaulan dan berteman dengan arif, dan diakhiri dengan berdoa.

\section{Penerapan Dakwah Sistem Langsung (DSL) di Kelas dan Mushola}

Penerapan dakwah sistem langsung (DSL), dimaksudkan untuk memberikan pemahaman yang bersifat komprehensif, selain dengan alat peraga ternyata DSL. Sangat membantu siswa dalam memahami pelajaran Pendidikan Agama Islam. Kegiatan ini dilakukan oleh siswa. Kegiatan ini menitik beratkan pada aspek motorik siswa disbanding kogniif. Kegiatan ini biasanya dilakukan di masjid, biasanya anak didik diminta untuk tadarus kemudian guru memberikan evaluasi, baik tajwid maupun makhrojnya.

\section{Shalat Dhuha, dan Dhuhur Berjamaah}

Pelaksanaan shalat dhuha dan dhuhur berjamah oleh siswa, dilaksanakan setiap hari. Shalat dhuha dilaksanakan pada jam istirahat pertama dan shalat dhuhur dilaksanakan pada istirahat kedua. Pembinaan keberagamaan dan sekaligus moralitas/sikap ini, sebagai upaya untuk pembiasaan sikap positif sesuai dengan tuntunan agama Islam dan manfaat waktu luang untuk beribadah.

\section{Pendampingan Teman Sebaya}

Pendampingan teman sebaya dilakukan oleh siswa, yang disusun oleh guru Pendidikan Agama Islam, dimaksudkan untuk memberikan pelayanan 
khusus siswa yang kurang dalam memahami materi agama Islam. Metode ini mampu memberikan peluang bagi siswa yang memerlukan pendampingan khusus.

\section{Sikap Ta'dim (Patuh) Kepada Guru}

Perilaku patuh pada guru sangat ditekankan. Hal ini sebagai pondasi terlaksananya proses kegiatan belajar mengajar di kelas. Sebagaimana yang terlihat hasil pengamatan peneliti, siswa/peserta didik melakukan jabat tangan dan mencium tangan gurunya ketika di sekolah. Pencerminan sikap tawadhu' inilah pembekalan dari sikap positif yang dikembangkan dalam membina keberagamaan remaja.

\section{Pendidikan ke-Nu-an}

Selain mendapatkan materi Pendidikan Agama Islam, kurikulum ke-Nuan sebagai nafas perjuangan keislamanpun diujikan. Pendidikan ke-Nu-an diajarkan, sebagai bentuk ciri khas keislaman.

\section{Peringatan Hari Besar Agama Islam}

Pembinaan moralitas/sikap sebagaimana yang dilaksanakan, dapat diaplikasikan dengan melaksanakan kegiatan peringatan hari besar agama Islam. hal ini dimungkinkan untuk memberikan pencerahan tentang upaya yang harus diteladani dari setiap tokoh (pemimpin). Siswa dapat memahami, melaksanakan ajaran dalam kehidupan di sekolah dan di masyarakat.

\section{Bakti sosial}

Dalam upaya mengembangkan sikap kepekaan serta merasakan sikap untuk membantu kepada orang tua, melaksanakan kegiatan bakti sosial sebagai bentuk pendidikan moralitas/sikap. Kegiatan ini sekaligus ajang promosi dalam pembinaan akhlak siswa. Siswa dapat berinteraksi dengan lingkungan panti asuhan sekitar. Hemat peneliti ternyata media bakti sosial ini dimanfaatkan siswa dalam membina ukhuwah Islamiyah.

Pembinaan keberagamaan dalam al-Qur'an dan Sunnah terdapat prinsipprinsip umum tentang pembinaan keberagamaan masyarakat yang harus kita jadikan landasan. Ada beberapa kaidah sosial atau prinsip-prinsip kemasyarakatan yang perlu diperhatikan oleh manusia dalam menyusun konsepsi bagi masyarakat, bangsa dan negara. Prinsp-prinsip sosial itu adalah sebagai berikut: 
Baik buruknya masyarakat tergantung kepada baik dan buruknya akhlak individu masyarakat itu. Dalam Q.S Al-Anfal ayat 53 :

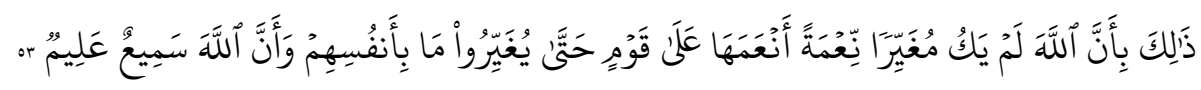

Artinya:"(Siksaan) yang demikian itu adalah karena sesungguhnya Allah sekalikali tidak akan meubah sesuatu nikmat yang telah dianugerahkan-Nya kepada suatu kaum, hingga kaum itu meubah apa-apa yang ada pada diri mereka sendiri, dan sesungguhnya Allah Maha Mendengar lagi Maha Mengetahui".

Maksud ayat tersebut menurut keterangan Tafsir Al-Maraghi ialah bahwa nikmat Allah yang telah di karuniakan-Nya kepada ummat manusia dan individu masyarakat tergantung kepada akhlak serta sifat-sifat dan amal perbuatannya ummat dan orang itu. Selama akhlak dan sifat perbuatannya baik, maka nikmat tersebut akan tetap juga Allah tidak akan menarik kembali nikmat itu dari mereka tanpa kezholiman mereka sendiri. Apabila mereka merubak akidah dan akhlak serta amal baiknya menjadi jelek, maka Allah akan merubah pula keadaan mereka dari merampas kembali nikmat yang telah Dia berikan, sehingga orang kaya bisa menjadi miskin, yang mulia dan berpangkat menjadi orang yang hina dina dan yang kuat akan menjadi lemah.

Kaidah sosial yang ketiga ini penting sekali diperhatikan dan direnungkan oleh generasi sekarang untuk dijadikan landasan dalam usaha pembinaan kualitas generasi muda yang nantinya akan memegang estafet kepemimpinan bangsa dan Negara. Pembinaan kualitas manusia tidak hanya dinilai dari segi intelektualnya, keterampilannya dan kesehatan jasmaniah, akan tetapi yang paling penting adalah kualitas rohaniah, kualitas akhlaknya. Atau dengan kata lain kita harus mengusahakan generasi penerus ini menjadi manusia-manusia yang shaleh bukan manusia yang bangga dengan amal perbuatan salah. Dalam pemeliharaan lingkungan hidup, alam lingkungan disekitar kita adalah ciptaan Allah untuk menjadi sumber kebahagiaan hidup manusia di dunia. Dia akan dapat dijadikan alat untuk mencapai kebahagiaan hidup di akhirat bilamana kita dapat memanfaatkannya sesuai dengan petunjuk Allah dan Rasul-Nya. Oleh karena kita harus memelihara lingkungan hidup ini dengan penuh rasa tanggung jawab, demi kebahagiaan hidup kita sendiri. Untuk memelihara lingkungan hidup kita harus memelihara keseimbangan dan memperbaiki yang sudah rusak. 


\section{SIMPULAN DAN SARAN}

\section{A. Simpulan}

Berdasarkan diskripsi data hasil penelitian dan pembahasan tentang strategi dan pendekatan duru Pendidikan Agama Islam dalam pembinaan keberagamaan remaja dapat disimpulkan sebagai berikut:

1. Strategi guru Pendidikan Agama Islam dalam pembinaan keberagamaan remaja disini dibagi menjadi tiga, yakni : 1. Strategi guru Pendidikan Agama Islam dalam membuat perencanaan pembinaan keberagamaan. Penyusunan perencanaan harus benar-benar dipertimbangkan lebih dahulu agar perencanaan yang telah dirancang berjalan sesuai dengan rencana dan mencapai tujuan yang diinginkan, 2. Strategi guru Pendidikan Agama Islam dalam pelaksanaan pembinaan keberagamaan. Untuk mempercepat keberhasilan pelaksanaan dalam meningkatkan kualitas pembelajaran dengan cara memberlakukan atau mengadakan kegiatan ekstra kurikuler yang bersifat wajib dengan mengambil pelajaran dari kitab kuning, 3. Strategi guru Pendidikan Agama Islam dalam evaluasi pembinaan keberagamaan. Di pertimbangkan dengan seksama yang kemudian melaksanakan program yang telah direncanakan secara maksimal, tetapi tetap ada kendala. Kendala yang dialami ini bersifat kondisional yang sulit diprediksi.

2. Pendekatan guru Pendidikan Agama Islam dalam pembinaan keberagamaan yang di pakai adalah menggunakan pendekatan kontekstual adapun pendekatan yang dilakukannya adalah 1. Perencanaan Pembelajaran yang dibuat oleh guru sudah baik, karena rencaanya untuk membuat siswa aktif dan antusias di dalam pembelajaran, 2. Proses pembelajaran yang dilakukan sesuai dengan langkah-langkah kontekstual, yang disajikan dalam bentuk kegiatan meliputi, pemahaman, penyajian ilmu pengetahua, keterampilan, nilai dan sikap yang dipelajari di kelas dengan kehidupan sehari-hari.

3. Keberagamaan Remaja. Terdapat beberapa pola pembinaan keberagamaan tersebut, antara lain: 1. Pembinaan yang dilakukan oleh guru Pendidikan Agama Islam mempunyai pengaruh positif terhadap keefektifan pembelajaran Pendidikan Agama Islam diantaranya guru harus menjadi uswatun hasanah bagi pribadinya dan siswanya terlepas dari sifat amoral. 2. Pembinaan keberagamaan oleh sekolah dan guru selain Pendidikan Agama Islam 
mempunyai pengaruh yang signifikan, yaitu adanya sistem Islamisasi ilmu pengetahuan dalam pendekatan disiplin ilmu, seluruh kegiatan dan mata pelajaran yang berada bersandarkan al-Qur'an dan Hadits.

\section{B. Saran}

Kajian tentang pembinaan keberagamaan remaja dalam penelitian ini lebih dekat pada kajian psikologi agama, sehingga hasil penelitian ini meskipun secara teori belum dapat digunakan sebagai bahan refrensi penulis karya ilmiah, namun setidaknya dapat digunakan sebagai bacaan tambahan untuk keperluan informasi terutama pada pembahasan yang serumpun dengan Psikologi Agama.

Selain itu penulis juga menyarankan kepada semua pihak baik pendidik, tokoh, pemerhati, lembaga pendidikan Agama kiranya berkenan memperhatikan hasil penelitian ini setidaknya sebagai bahan diskusi dan pembanding untuk merumuskan bahkan memprediksi munculnya pembinaan keberagamaan baru di masa yang akan datang, sehingga pembinaan-pembinaan yang ter "indikasi" destruktif dapat diantisipasi lebih dini.

\section{DAFTAR PUSTAKA}

Al-Qur'an Al-karim dan Terjemahannya. (2001). Semarang: PT. Karya Toha Putra.

Ahmad Ahyadi. (1988). Pengantar Psikologi Agama. Bandung.

Depag RI. (1983). Pola Pembinaan Mahasiswa IAIN. Jakarta: Direktorat Pembinaan Perguruan Tinggi Agama Islam.

Departemen Pendidikan dan Kebuyaan. (1988). Kamus Besar Bahasa Indonesia. Jakarta: Balai Pustaka.

Djamaludin Anchor \& Surosono, F.N, (2011). Psikologi Islam: Solusi Islam atas Problemproblem Psikologi. Yogyakarta: Pustaka Pelajar. Cet.VIII.

Ghufron Su'udi. (tth). Mencari Sosok Pembina dalam Rangka Mewujudkan Generasi Muda Islam. Semarang: Depag RI.

Hamdani. M.A. (2011). Strategi Belajar Mengajar . Bandung: CV. Pustaka Setia.

Hamruni. (2012). Strategi Pembelajaran. Yogyakarta: Insan Madani.

Hurlock. E.B. (1980). Psikologi Perkembangan suatu Pendekatan Sepanjang Rentang Kehidupan. Jakarta: PT. Gelora Aksara Pratama. 
88 | Arni Zulianingsih

Jalaludin, (2016). Psikologi Agama. Jakarta: PT. Raja Grafindo Persada.

Marimba. A.D. (1980). Filsafat Pendidikan Islam. Bandung: Al-Ma'arif. Cet. IV.

Muhaimin. (2006). Nuansa Baru Pendidikan Islam \& Mengurai Benang Kusut Dunia Pendidikan. Jakarta: PT. Raja Grafindo Persada.

Zakiyah Daradjad. (1995). Remaja :Harapan dan Tantangan. Jakarta: Ruhana. Cet-II. (1976). Pembinaan Remaja. Jakarta: Bulan Bintang. Cet. II. 